\title{
WEB-BASED COOPERATIVE LEARNING, LEARNING STYLES, AND STUDENT'S LEARNING OUTCOMES
}

\author{
Bambang Hariadi \\ STIKOM Surabaya \\ email: bambang@stikom.edu
}

\begin{abstract}
This study was aimed to examine the effect of the instructional learning strategy (webbased STAD-type cooperative and text-based STAD-type cooperative learning strategies) and learning styles towards student learning achievement. This quasi-experimental study used a non-equivalent control group version of the factorial design. The subjects were the first-semester undergraduate students of Information Systems at STIKOM Surabaya. Sixty-nine (69) students were involved, 34 of whom were the subjects of the experimental group and 35 were the subjects of the control group. The collected data were statistically analyzed by using the two-way analysis of variance technique (ANOVA) with the significance level of 0.05 . The findings of this research indicate that there was a significant difference in learning achievement, for the General Management course, between groups of students taught with the web-based STAD-type cooperative learning strategies and those taught with the text-based STAD-type cooperative learning strategies. Based on the findings, the researcher suggests lecturers to implement the STAD-type cooperative learning strategies, and use the web-based and text-based strategies simultaneously (complementarily) in the form of blended learning.
\end{abstract}

Keywords: learning strategy, STAD type cooperative, web based learning, learning styles, learning outcomes

\section{PEMBELAJARAN KOOPERATIF BERBASIS WEB, GAYA BELAJAR, DAN HASIL BELAJAR MAHASISWA}

\begin{abstract}
Abstrak: Penelitian ini bertujuan untuk menguji pengaruh strategi pembelajaran (kooperatif tipe STAD berbasis web vs kooperatif tipe STAD berbasis teks) dan gaya belajar terhadap hasil belajar mahasiswa. Penelitian kuasi eksperimen ini menggunakan desain faktorial versi nonequivalen control group design. Subjek penelitian ini adalah mahasiswa program studi Sistem Informasi semester I di STIKOM Surabaya yang berjumlah 69 mahasiswa, terdiri dari 34 mahasiswa untuk kelas eksperimen dan 35 mahasiswa untuk kelas kontrol. Data yang terkumpul diolah secara statistik dengan menggunakan teknik analisis varian dua jalur dengan menggunakan taraf signifikansi 0,05 . Hasil penelitian ini menunjukkan bahwa terdapat perbedaan hasil belajar mata kuliah Manajemen Umum yang signifikan antara kelompok mahasiswa yang dibelajarkan dengan strategi kooperatif tipe STAD berbasis web dan strategi kooperatif tipe STAD berbasis teks. Berdasarkan temuan penelitian ini disarankan untuk menerapkan strategi pembelajaran kooperatif tipe STAD dan menggunakannya secara bersamaan (saling melengkapi) antara yang berbasis web dengan yang berbasis teks dalam bentuk blended learning.
\end{abstract}

Kata Kunci: strategi pembelajaran, kooperatif tipe STAD, web base learning, gaya belajar, hasil belajar

\section{INTRODUCTION}

Student Teams-Achievement Devisions (STAD) type cooperative learning strategy is a cooperative learning strategy that group students into small teams. In this STAD-type cooperative learning strategy, a lecturer acts as a facilitator so that the learning process would involve many students in group activities with three to five students per group. Each group comprises of various gender, performance level, ethnicity and other student characteristics (Slavin, 1995). In this diversed group, each member cooperates to achieve the learning objectives. In this STAD-type cooperative learning strategy, the students' tasks are not only to work as a team, but also to learn as a team (Nur, 2008). 
Therefore, every student as a team member can learn how to position themselves and implement the cooperative value within an organisation or a team in order to reach their goal.

Related studies on the Students Teams Achievement Devision (STAD) type cooperative learning indicated a positive result, however, these studies did not use the web as a media. Noornia (1997) stated that the STAD-type cooperative learning: (1) bring a positive influence towards student's learning activity; (2) increase student's understanding; (3) provide specific knowledge for students in the above average group and for those who are lacking; and (4) increase awareness among the group members which might otherwise not arise from a conventional learning. Machmuda (2007) also found that the STAD-type cooperative learning is effective in increasing students' ability in learning Arabic, especially in reading (maharoh qiro'ah). Research findings of Zainuddin (2002) show that the STAD-type cooperative learning with field independent (FI) and field dependent (FD) cognitive-style concentration in mathematics had significantly improved student's learning performance. Furthermore, Mulyadi (2009) also found that a VCD optimization learning strategy in physics through cooperative model had improved student's performance and achievement.

The presence of information technology has created a computer based learning in the form of a web based learning environment like computer based learning (CBL), web based learning (WBL), as well as web based teaching (WBT). Setyosari (2006) concluded a few points relating to information technology in learning as follow: (1) it increases student's performance in knowledge, skills and attitude; (2) students are more likely to study through a computer than a television; (3) students like an interactive participation role more than a passive participation role; (4) an effective computer application program actively involves students and students can freely control; and (5) combining computer technology into learning can improve students' attitude positively toward school, teaching and learning in general.
An innovative learning process is marked by learning activities that are not only giving the knowledge to students, but students also have to be given the opportunity to construct the knowledge through their own way as a realization toward tasks and their responsibility (Nur \& Wikandari, 2000). Moreover, Slavin (2000) added that lecturers can help the knowledge construction process by organizing a learning process that make information more meaningful and relevant for the students, giving the opportunity for the students to find and implement their own ideas, also stimulating the students to realize and utilize their own strategies to learn.

Cheong and Cheong (2008) conducted a research about critical thinking for early year students in high school in an online asynchronous discussion environment. In their research Cheong dan Cheong (2008) found that student's perception about online discussion is positive and that there was a critical thinking skills throughout the online discussion. Milne et al. (2008) conducted a study toward the use of elearning tools to support assessment of assignments. The study found that there was a strong advantage in reducing the staff workload when assessing assignments using e-learning tools. So far, this advantage is only used by a small number of scholars and there is a huge potential for further application of e-learning tools and other related approaches. These findings, found by Cheong dan Cheong (2008) and Milne et.al. (2008), show that the use of web in learning has advantages in improving the learning outcomes.

There are three learning styles that can be developed for students. These are: visual, auditory, and kinesthetic. In learning, there is a possibility for students to develop these three learning styles in an integrated manner. Rose and Nicholl (2002) mentioned that each individual stores visual $(\mathrm{V})$, auditory $(\mathrm{A})$, and kinesthetic $(\mathrm{K})$ memory in different parts of the brain. Therefore, a multi-sensory way in learning is the most effective.

A combination of a face-to-face learning and a web-based learning (blended learning) can improve the learning outcomes. McCarthy 
(2010) suggests blended learning coupled with face-to-face discussions is useful in improving the understanding of the material being taught and the level of involvement in the group. Blended learning is a great way to learn about other students in learning. According to Serin and Cyprus (2011), computer-based learning can improve performance and problem solving skills of students. The development of webbased learning models blended with cooperative learning strategies has been done by Chantanarungpak and Rattanapian (2006). From this development, it is known that learning with web-based cooperative model can improve learning outcomes as well as a pleasant alternative learning strategies for learners.

Some research findings also indicate that the link between learning strategy and learning styles influence the learning outcomes. Pasaribu (2005) suggests there is an interaction between the different learning styles (visual and auditory) and different learning media (posters and tapes) on Indonesian descriptive writing skills in class I packet B. Nurlaela (2007) also found an interaction between learning model and the student's learning style on the learning outcomes. Based on this, it is necessary to analyze the effects of interaction between learning strategies and learning styles on student learning outcomes of cognitive and affective aspects.

\section{METHODS}

This study used a factorialized $(2 \times 3)$ version of the non-equivalent control group design. The factorial design divides the groups based on the number of treatment types and groups that will be studied. This study design of this study can be illustrated by the chart in Figure 1.

The subjects were students of Information Systems in their first semester of the academic year 2011/2012 at STIKOM Surabaya, totaling 69 students, consisting of 34 students for the experimental group and 35 students for the control group. The collected data were analyzed with the data analysis design as shown in Table 1.

\begin{tabular}{|ccc|}
\hline $\mathrm{O}_{1}$ & $\mathrm{X}_{1} \mathrm{Y}_{1}$ & $\mathrm{O}_{2}$ \\
$\mathrm{O}_{1}$ & $\mathrm{X}_{1} \mathrm{Y}_{2}$ & $\mathrm{O}_{2}$ \\
$\mathrm{O}_{1}$ & $\mathrm{X}_{1} \mathrm{Y}_{3}$ & $\mathrm{O}_{2}$ \\
--------------- \\
$\mathrm{O}_{3}$ & $\mathrm{X}_{2} \mathrm{Y}_{1}$ & $\mathrm{O}_{4}$ \\
$\mathrm{O}_{3}$ & $\mathrm{X}_{2} \mathrm{Y}_{2}$ & $\mathrm{O}_{4}$ \\
$\mathrm{O}_{3}$ & $\mathrm{X}_{2} \mathrm{Y}_{3}$ & $\mathrm{O}_{4}$ \\
\hline
\end{tabular}

Figure 1 Research Design Factorialized (2 $x$ 3) version of the Non-equivalent Control Group Design. Adapted from Tuckman (1999:172-175)

Information:

$\mathrm{O}_{1}$ dan $\mathrm{O}_{3}$ : initial observation (pre test)

$\mathrm{O}_{2}$ dan $\mathrm{O}_{4}$ : final observation (post test)

$\mathrm{X}_{1} \quad$ : treatment (experimental group) in the form of web-based STAD-type cooperative learning strategy implementation

$\mathrm{X}_{2} \quad$ : treatment (control group) in the form of text-based STAD-type cooperative learning strategy implementation

$\mathrm{Y}_{1} \quad$ : visual learning style

$\mathrm{Y}_{2} \quad$ : auditory learning style

$\mathrm{Y}_{3} \quad$ : kinesthetic learning style

---------- : subject/group is not determined by random (intact group)

Table 1 Research Data Analysis Design

\begin{tabular}{clcc}
\hline \multirow{2}{*}{$\begin{array}{c}\text { Moderator } \\
\text { Variable }\end{array}$} & \multicolumn{1}{c}{$\begin{array}{c}\text { Free } \\
\text { Variable }\end{array}$} & \multicolumn{2}{c}{$\begin{array}{c}\text { Learning Strategy } \\
\text { STAD-type Cooperative }\end{array}$} \\
\cline { 3 - 4 } & & Web based & Text based \\
\hline Learning & Visual & 12 & 12 \\
Style & Auditory & 11 & 12 \\
& Kinesthetic & 11 & 11 \\
\hline
\end{tabular}

There are three variables in this study, they are independent variable, moderator variable and dependent variable. The independent variable in this study is the learning strategy that includes a web-based STAD-type cooperative learning strategy (Arends, 2007) and a text-based STAD-type cooperative learning strategy (Nasution, 2009). Moderator variable in this study is the learning styles of students 
that were divided into three: visual learning style, auditory learning style and kinesthetic learning style (Madden, 2002; DePorter and Hernacki, 2007; Nasution, 2009). The dependent variable in this study is the learning outcomes, which are grouped into (1) cognitive ability that measure the student's mastery of the learning materials, which is done by a test to measure the level of their understanding $(\mathrm{C} 1$, $\mathrm{C} 2, \mathrm{C} 4, \mathrm{C} 5)$ and (2) affective ability (A1- A3) to measure the attitudes of students, which is done through observations (Anderson et al, 2001).

Data collection is performed through the following steps: (1) perform an initial test; (2) perform a learning styles test; (3) carry out a learning treatment (experimental); (4) perform an observation; and (5) measure the learning outcomes. The study was conducted as much as 7 sessions in each class; one session to perform the initial test and the learning styles test, five sessions to study and observe, and one session to measure the learning outcomes.

The instruments used in this study were: (1) learning outcomes test, and (2) learning styles test. The learning outcomes test is developed based on the learning objectives in the sub topics that were used as a learning trial to meet the curricular validity (Surachmad, 1990). The learning styles test uses a questionnaire that was adopted from the learning styles test which were used by DePorter et.al. (2000). The researcher developed these instruments through two phases: development and trial phase. The trial of the instruments is performed to determine the validity and the reliability of the instruments used in this study.

Data analysis technique used in this study was conducted by descriptive and inferential statistics. To test the hypothesis, this research was conducted through two phases, namely an assumption analysis testing phase and a hypothesis testing phase. Description analysis for analysis assumption testing, namely; test for normality of data distribution and test for variance homogeneity. The normality test was done by the Kolmogorov-Smirnov test through SPSS for Windows version 16. The data homogeneity test was done by the Lavene's test, which is a component of the ANOVA program package. The decision to declare the distribution normality and variance homogeneity was based on the error level of $5 \%$ or the confidence level of $95 \%$. The research hypothesis testing used inferential statistical analysis technique using a factorial pattern ANOVA that was processed through SPSS for Windows version 16. The ANOVA was also used to determine the interaction of these two factors (learning strategies and learning styles) on the learning outcomes. The decisions that were used to express the influence of the independent variable on the dependent variable are based on the error level of $5 \%$ or the confidence level of $95 \%$.

\section{RESULTS Results Data of the Learning Styles Ques-
tionnaire}

The calculation results data of the learning styles questionnaire which was given to students in two groups (one experimental group and one control group) totaling 69 students in each learning style can be described as follows. (1) Students who have a visual learning style totalling 24 people had achieved the highest score of 86 and the lowest score of 60 , range of 26 , variance of 46.08 , standard deviation of 6.788 , average (mean) of 74.58 , and median of 74.74. (2) Students who have an auditory learning style totalling 23 people have achieved the highest score of 86 and the lowest score of 64 , range of 22, variance of 49.265, standard deviation of 7.019, average (mean) of 73.91, and median of 72.1. (3) Students who have a kinesthetic learning style totalling 22 people have achieved the highest score of 84 and the lowest score of 60, range of 24, variance of 58.190, standard deviation of 7.628, average (mean) of 73 , and median of 74 .

\section{Learning Outcomes Data of the Cognitive Aspect of General Management Course}

Data Summary description of the learning outcomes of the cognitive aspect of General Management course obtained through the descriptive statistical calculation for the group using the web-based STAD-type cooperative 
learning strategy and the text-based STAD-type cooperative is presented in Table 3.

Table 3. Summary of Learning Outcomes Data of the Cognitive Aspect of General Management Course

\begin{tabular}{clccc}
\hline $\begin{array}{c}\text { Cooperative } \\
\text { Learning } \\
\text { Strategy }\end{array}$ & $\begin{array}{c}\text { Learning } \\
\text { Style }\end{array}$ & Mean & $\begin{array}{c}\text { Std. } \\
\text { Deviation }\end{array}$ & N \\
\hline Web-based & Visual & 78.67 & 8.794 & 12 \\
& Auditory & 83.27 & 8.730 & 11 \\
& Kinesthetic & 72.36 & 8.524 & 11 \\
& Total & 78.12 & 9.534 & 34 \\
Text-based & Visual & 66.17 & 9.666 & 12 \\
& Auditory & 74.17 & 9.476 & 12 \\
& Kinesthetic & 74.00 & 8.390 & 11 \\
Total & Total & 71.37 & 9.723 & 35 \\
& Visual & 72.42 & 11.065 & 24 \\
& Auditory & 78.52 & 10.058 & 23 \\
& Kinesthetic & 73.18 & 8.296 & 22 \\
& Total & 74.70 & 10.145 & 69 \\
\hline
\end{tabular}

\section{Learning Outcomes Data of the Affective Aspect of General Management Course}

Post-test data were obtained from an observation in a role-play activity affective aspect of General Management course after treatment. Improvement of student's learning outcomes on the affective aspect of General Management course can be seen by looking at the average score. Data summary of observation description of the affective learning outcomes on the General Management course, which was obtained through the calculation of descriptive statistics of student groups treated with implementing the web-based STAD-type cooperative learning strategy and text-based STAD-type cooperative, is presented in Table 4.

\section{Hypothesis Testing \\ Data of Cognitive Aspect Learning Outcomes}

Hypothesis testing is done by analyzing the test data of learning outcomes of the cognitive aspect of General Management course. After the two-way analysis of variance technique (ANOVA) calculation is performed on the significance level of 0.05 with the help of SPSS release 16, the results are obtained and are presented in Table 5.
Table 4. Summary of Learning Outcomes Data of the Affective Aspect of General Management Course

\begin{tabular}{clccc}
\hline $\begin{array}{c}\text { Cooperative } \\
\text { Learning } \\
\text { Strategy }\end{array}$ & $\begin{array}{c}\text { Learning } \\
\text { Style }\end{array}$ & Mean & $\begin{array}{c}\text { Std. } \\
\text { Deviation }\end{array}$ & $\mathrm{N}$ \\
\hline Web-based & Visual & 70.17 & 5.424 & 12 \\
& Auditory & 70.18 & 6.161 & 11 \\
& Kinesthetic & 67.27 & 5.605 & 11 \\
& Total & 69.24 & 5.721 & 34 \\
Text-based & Visual & 79.00 & 4.936 & 12 \\
& Auditory & 77.33 & 6.110 & 12 \\
& Kinesthetic & 78.73 & 4.315 & 11 \\
Total & Total & 78.34 & 5.099 & 35 \\
& Visual & 74.58 & 6.788 & 24 \\
& Auditory & 73.91 & 7.019 & 23 \\
& Kinesthetic & 73.00 & 7.628 & 22 \\
& Total & 73.86 & 7.065 & 69 \\
\hline
\end{tabular}

From the calculation of the hypothesis testing above, it can be summarised as follows.

- There is a significant difference in learning outcomes of the cognitive aspect of General Management course between students who used the web-based STAD-type cooperative learning strategy and those who used the text-based STAD-type cooperative.

- There is a significant difference in learning outcomes of the cognitive aspect of General Management course between groups of students who have visual, auditory and kinesthetic learning styles.

- There is an interaction influence between the learning strategy (web-based STAD-type cooperative and text-based STAD-type cooperative) and the student's learning style on the cognitive aspect learning outcomes of General Management course.

\section{Data of Affective Aspect Learning Outcomes}

Hypothesis testing of the affective aspect learning outcomes data is done by analyzing the test data of the affective aspect of General Management course. After the calculation of the two-way analysis of variance technique (Anova) on the significance level of 0.05 with the help of SPSS release 16, the results are obtained and are presented in Table 6. 
Table 5. Result Summary of the Two-Way Analysis of Variance Technique Calculation on the Significance Level $\alpha=0,05$ (Cognitive Aspect)

\begin{tabular}{|c|c|c|c|c|c|}
\hline Source & $\begin{array}{l}\text { Type III Sum of } \\
\text { Squares }\end{array}$ & $\mathrm{df}$ & Mean Square & $\mathrm{F}$ & Sig. \\
\hline Corrected Model & $1939.881^{\mathrm{a}}$ & 5 & 387.976 & 4.832 & .001 \\
\hline Intercept & 385047.036 & 1 & 385047.036 & 4.795E3 & .000 \\
\hline Learning Strategy & 762.900 & 1 & 762.900 & 9.501 & .003 \\
\hline Learning Style & 546.523 & 2 & 273.262 & 3.403 & .039 \\
\hline Learning Strategy * Learning Style & 616.845 & 2 & 308.423 & 3.841 & .027 \\
\hline Error & 5058.727 & 63 & 80.297 & & \\
\hline Total & 391980.000 & 69 & & & \\
\hline Corrected Total & 6998.609 & 68 & & & \\
\hline
\end{tabular}

a. R Squared $=.277$ (Adjusted R Squared $=.220$ )

Table 6. Result Summary of the Two-Way Analysis of Variance Technique Calculation on the Significance Level $\alpha=\mathbf{0 , 0 5}$ (Affective Aspect)

\begin{tabular}{lrrrrr}
\hline \multicolumn{1}{c}{ Source } & $\begin{array}{c}\text { Type III Sum } \\
\text { of Squares }\end{array}$ & df & Mean Square & F & Sig. \\
\hline Corrected Model & $1512.217^{\mathrm{a}}$ & 5 & 302.443 & 10.123 & .000 \\
Intercept & 374893.759 & 1 & 374893.759 & $1.255 \mathrm{E} 4$ & .000 \\
Learning Strategy & 1440.369 & 1 & 1440.369 & 48.208 & .000 \\
Learning Style & 28.847 & 2 & 14.424 & .483 & .619 \\
Learning Strategy * Learning Style & 52.706 & 2 & 26.353 & .882 & .419 \\
Error & 1882.333 & 63 & 29.878 & & \\
Total & 379760.000 & 69 & & & \\
Corrected Total & 3394.551 & 68 & & & \\
\hline
\end{tabular}

a. R Squared $=.445$ (Adjusted R Squared $=.401)$

From the calculation of the hypothesis testing above, it can be summarised as follows:

- There is a significant difference in learning outcomes of the affective aspect of General Management course between students who used the web-based STAD-type cooperative learning strategy and those who used the text-based STAD-type cooperative.

- There is no significant difference in learning outcomes of the affective aspect of General Management course between groups of students who have visual, auditory and kinesthetic learning styles.

- There is no interaction influence between the learning strategy (web-based STAD-type cooperative and text-based STAD-type cooperative) and the student's learning style on the affective aspect learning outcomes of General Management course.

\section{Discussion}

Impacts of Learning Strategies on the Learning Outcomes of the Cognitive Aspect of General Management

The hypothesis testing result showed that there was a significant difference in the learning outcomes of General Management course between groups of students studying with the webbased STAD-type cooperative learning strategy and the text-based STAD-type cooperative learning strategy. The test data calculation of General Management learning outcomes showed that through the implementation of the webbased STAD-type cooperative learning strategy, an average score of 78.12 was obtained and an average score of 71.37 was obtained through the implementation of the text-based STADtype cooperative learning strategy. 
This means that the implementation of the web-based STAD-type cooperative learning strategy has proven to have a better influence on the learning outcomes of General Management course compared to the text-based STADtype cooperative learning strategy. These findings are consistent with the previous studies, which compares conventional learning (face to face) with the computer-assisted learning and web-based (blended learning), namely: the study results of Chantanarungpak and Rattanapian (2006), McCarthy (2010), Ghauth and Abdullah (2010), Serin and Cyprus (2011). Learning with multimedia or e-learning can obtain better learning outcomes compared to the conventional learning without media.

Several factors are believed to be the cause of the better learning outcomes in the implementation of the web-based STAD-type cooperative learning strategy compared to the text-based STAD-type cooperative learning strategy. First, the web-based STAD-type cooperative learning strategy is one of the learning strategies which is based on a constructivist view. According to the constructivist theory, learning is an effort of value provision by the student on their experiences through assimilation and accommodation towards the formation of their cognitive structures (Degeng, 1997). Second, the web-based STAD-type cooperative learning strategy is able to motivate and promote the active participation of students in learning. Third, based on the theoretical and empirical foundation, the web-based STAD-type cooperative learning strategy (average of 78.12) is superior to the text-based STAD-type cooperative learning strategy (average of 71.37). Research findings by Hartono (2014:13) showed that in a web-based learning, students are active in downloading materials, commenting, discussing, and following links with the other community members.

\section{Impacts of Learning Styles on the Learning Outcomes of the Cognitive Aspect of General Management}

A group of students who have an auditory learning style had obtained better learning outcomes compared to the other groups of students with visual and kinesthetic learning styles. This is evidenced by the results of the learning outcomes test data calculation that a group of students who have an auditory learning style obtained an average score of 78.52, a group of students who have a kinesthetic learning style obtained an average score of 73.18, and a group of students who have a visual learning style obtained an average score of 72.42. These results indicate that learning style factor is proven to have a significant impact on the learning outcomes of the cognitive aspect of General Management course.

This study results support the results of previous studies conducted by Madden (2002) and Nasution (2009), that learning styles affect the learning outcomes. Students who have an auditory learning style obtained better learning outcomes compared to students who have visual and kinesthetic learning styles. In addition, it also strengthens the research results of Nurlaela (2007) and Sulistiyawati (2011) which concluded that there is a significant influence of visual and kinesthetic learning styles on the student's achievements.

\section{Impacts of the Interaction between Learning Strategies and Learning Styles on the Learn- ing Outcomes of the Cognitive Aspect of Ge- neral Management}

Based on the hypothesis testing, it was concluded that there is an interaction influence between learning strategies and learning styles on the learning outcomes of the General Management course. It shows that the student's achievements are not only a result of the implementation of learning strategies, but are also influenced by the student's learning styles. The student's learning styles have an impact on the application of learning strategies in achieving the learning objectives (learning outcomes).

This study results support some expert opinions, among others Slavin (1997), Lyle and Robinson (2001) and Degeng (2007), which stated that the learning outcomes are largely determined by the implemented learning strategies and the student's characteristics. Degeng 
(2007) suggested that the learning outcomes are all effects that can be used as a value indicator of the implementation of learning strategies under different conditions. In line with these opinions, Lyle and Robinson (2001) stated that the learning conditions affects the effectiveness and efficiency of the learning strategy implementation, which means that the effectiveness and efficiency of the learning strategy implementation is influenced by the student's characteristics. Triwik Srimulati, Kuswati and Aprilinawati (2014: 117) stated that each learning strategy has advantages and disadvantages. There is no one best learning strategy, but the use of a learning strategy should be tailored to the learning objectives.

\section{Impacts of Learning Strategies on the Learn- ing Outcomes of the Affective Aspect of Ge- neral Management}

The hypothesis testing result showed that the implementation of the text-based STADtype cooperative learning strategy is proven to have a better effect on the learning outcomes of the affective aspect of General Management course compared to the web-based STAD-type cooperative learning strategy. These findings are consistent with the previous research conducted, such as: the research results of Noornia (1997), Zainuddin (2002), Machmuda (2007) and Mulyadi (2009), which showed that the cooperative learning strategies can provide a significant result to the improvement of learning achievement.

There are several factors believed to be the cause of better learning outcomes on the text-based STAD-type cooperative learning strategy compared to the web-based STAD-type cooperative learning strategy. First, in the textbased STAD-type cooperative learning strategy, the discussion process among students occurs physically so that expressions from the psychological elements can be viewed and practiced directly into real behavior. Second, the textbased STAD-type cooperative learning strategy is capable of motivating and improving active participation of students in learning. Third, based on the theoretical and empirical foun- dation, the text-based STAD-type cooperative learning strategy (average of 78.34) is superior to the web-based STAD-type cooperative learning strategy (average of 69.24).

\section{Impacts of Learning Styles on the Learning Outcomes of the Affective Aspect of General Management}

The hypothesis testing concluded that there is no significant difference in the learning outcomes of the affective aspect of General Management course between groups of students who have visual, auditory and kinesthetic learning styles. These results indicate that learning style factor is not proven to have a significant impact on the learning outcomes of the affective aspect of General Management course.

This study results support the previous research conducted by Brown et. al. (2009) who found that learning style is accounted for a small percentage (not significant) of the preferred sub-scale variances. Likewise, the research of Halis (2006) who found that different learning styles do not provide any real impact on the learning outcomes of the drip installation skill. This suggests that learning styles do not affect the attainment of the affective aspect of learning outcomes.

Impacts of the Interaction between Learning Strategies and Learning Styles on the Learning Outcomes of the Affective Aspect of General Management

The hypothesis testing showed that there is no interaction effect between learning strategies and learning styles on the learning outcomes of the affective aspect of General Management. The influence of learning strategies on the learning outcomes that have been presented on the study results showed that learning strategies provide a powerful main influence on the student's affective aspect of learning outcomes. Theoretical studies, as revealed by Slavin (1997), Arends (2007), and Lie (2008), that a cooperative learning strategy provides a wide opportunity to students to be actively involved in learning. 
These research findings indicate that learning strategies provide a very strong influence on the affective aspect of the learning outcomes, while learning styles do not have an effect on the learning outcomes, therefore, there is no interaction influence between learning strategies and learning styles on the learning outcomes of the affective aspect of General Management course. Results of this study are confirmed by Halis (2006) and Nurlaela (2007), who suggest that there is no difference in the learning outcomes as a result of the interaction between the use of learning media and learning styles on the learning outcomes.

\section{CONCLUSION}

Based on the presentation of research results and discussion above, it can be concluded that: (1) there are significant differences in the learning outcomes of the General Management course between groups of students that learned with the web-based STAD-type cooperative learning strategy and the text-based STAD-type cooperative strategy; (2) the learning outcomes of the cognitive aspect of General Management course between groups of students who have visual, auditory and kinesthetic learning styles differ significantly, while the learning outcomes of the affective aspect of General Management course between groups of students who have visual, auditory and kinesthetic learning styles do not differ significantly; and (3) learning strategies and learning styles show an interaction impact on the learning outcomes of the cognitive aspect of General Management course, while learning strategies and learning styles show no interaction impact on the learning outcomes of the affective aspect of General Management course.

Results of this study indicate that the implementation of learning strategies and learning media in accordance with the learning objectives can improve the learning outcomes, but it still requires the presence of students to reinforce the learning outcomes. Therefore, the use of learning media, in this case a web-based (internet) can not replace the lecturer (learner) in the learning process, because the presence of learners is still required. The optimum learning outcomes can be achieved by using the internet as a medium of learning, which collaborate with a conventional learning to complement the learning process in the form of blended learning or hybrid learning.

\section{RECOMMENDATION}

Based on the research findings, the following are suggested: (1) for lecturers, in implementing the STAD-type cooperative learning strategies, to use the web-based and text-based simultaneously (complementarily) in the form of blended learning; (2) to conduct a research to test the three aspects of learning outcomes by Bloom, namely: cognitive, affective and psychomotor or the attainment of learning outcomes from the Gagne's taxonomy: the ability of verbal information, intellectual skills, cognitive strategies, attitudes and motor skills; and (3) to do further study and/or research to improve the learning quality in the form of research and development that promote the quality improvement of learning process and outcomes.

\section{ACKNOWLEDGMENTS}

The author would like to thank the Journal Editors of the Cakrawala Pendidikan UNY and the reviewers of this research journal article who have provided input to this article so that it can be published in the Cakrawala Pendidikan $U N Y$ journal. Hopefully this article would be useful to readers.

\section{REFERENCES}

Anderson, L.R.; Krathwohl, D.R.; Airasian, P.W.; Cruikshank, K.A.; Mayer, R.E.; Pintrich, P.R.; Raths, J.; Wittrock, M.C. 2001. A Taxonomy For Learning, Teaching, and Assesing: A Revision of Bloom's Taxonomy of Educational Objectives. A Bridged Edition. New York: Longman.

A rends, R.I. 2007. Learning to Teach ( $7^{\text {th }}$ ed.). $\mathrm{N}$ ew Y ork: $\mathrm{M}$ CG raw-Hill Co.

Brown, Ted; Zoghi, Maryam; Williams, Brett; Sim, Jenny; Ann-Holt, Tangerine. 2009. 
"Are Learning Style Preferences of Health Science Students Predictive of Their Attitudes Towards e-Learning?" Australasian Journal of Educational Technology. 25 (4), 524-543.

Chantanarungpak, K. dan Rattanapian, V. 2006. "Development of a Web-Base Instruction Model Blended with Cooperative Learning in Mathematics for Upper Primary School Student". Proceedings of International Conference "e-Learning: Learning Theories vs Technologies?”. Ramkhamhaeng University, Bangkok. 14-16 Desember 2006.

Cheong, C.M. dan Cheong, W.S. 2008. Online "Discussion and Critical Thinking Skills: A Case Study in a Singapore Secondary School". Australasian Journal of Educational Technology. 24(5), 556-573.

Degeng, I.N.S. 1997. Media Pembelajaran: Makalah Pelatihan Staf, Guru dan Karyawan Sekolah Ciputra. Surabaya, April - Mei 1997.

DePorter, B. dan Hernacki, M. 2007. Quantum Learning: Unleashing the Genius In You. Penerjemah: Alwiyah Abdulrahman. Penyunting: Sari Meutia. Bandung: Kaifa.

Ghauth, K.I. dan Abdullah, N.A. 2010. "Measuring Learner's Performance in e-Learning Recommender Systems". Australasian Journal of Educational Technology. 26 (6), 764-774.

Halis, F.D.K. 2006. "Pengaruh Penggunaan Media Pembelajaran dan Gaya Belajar Mahasiswa terhadap Hasil Belajar Keterampilan Memasang Infus pada Mahasiswa Politeknik Kesehatan Malang". Tesis. Tidak diterbitkan. Malang: PPS Universitas Negeri Malang.

Hartono. 2014. "Efektivitas Webblog dan Facebook Terintegrasi Untuk Pembelajaran Virtual". Jurnal Cakrawala Pendidikan, vol. 33 , No. 1.

Lie, A. 2008. Cooperative Learning: Mempraktikkan Cooperative Learning di RuangRuang Kelas. Jakarta: PT. Grasindo.
Lyle, K.S. dan Robinson, W.R. 2001. Teaching Science Problem Solving: an Overview Experiment. (online) (http://Kennet@ williamsr.edu diakses 10 Maret 2010.

Machmudah, U. 2007. Pengaruh Penggunaan Metode Cooperative Learning Model STAD terhadap Hasil Belajar Maharoh Qiro'ah I dan Sosial Skill (Kemampuan Komunikasi dan Kolaborasi) pada Maharoh Qiro'ah I. Malang: LPM UIN.

Madden, T.L. 2002. Fire-Up Your Learning: an Accelerated Learning Action Guide. Alih Bahasa: Ivonne Suryana. Jakarta: PT. Gramedia Pustaka Utama.

McCarthy, J. 2010. "Blended Learning Environments: Using Social Networking Sites to Enhance the First Year Experience". Australasian Journal of Educational Technology. 26(6), 729-740. (online http://www.ascilite.org.au/ajet/ajet26/ mccarthy.pdf diakses 3 September 2011).

Milne, J.; Heinrich, E. dan Morrison, D. 2008. "Technological Support for Assignment Assessment: A New Zealand higher Education Survey". Australasian Journal of Educational Technology. 24(5), 487-504.

Mulyadi, E. 2009. "Optimalisasi VCD Pembelajaran Fisika melalui Model Kooperatif sebagai Upaya Peningkatan Kinerja dan Prestasi Siswa Kelas XI di SMK". Proceding Seminar Internasional "Information and Communication Technology (ICT) in Education di UNY pada 13-14 Pebruari 2009.

Nasution, S. 2009. Berbagai Pendekatan dalam Proses Belajar \& Mengajar. Jakarta: Bumi Aksara.

Noornia, A. 1997. "Penerapan Pembelajaran Kooperatif dengan Metode STAD pada Pengajaran Persen di Kelas IV SDI Ma'arif 02 Pematang Singosari". Tesis, Tidak Diterbitkan. Malang: PPS UM.

N ur, M . \& W ikandari, P. R. 2000. Pengajaran Berpusat Kepada Siswa dan Pendekatan K onstruktivis dalam Pengajaran. Surabaya: U niversity Press. 
Nurlaela, L. 2007. "Pengaruh Model Pembelajaran, Gaya Belajar dan Kemampuan Membaca terhadap Hasil Belajar Siswa SD di Kota Surabaya". Disertasi. Tidak Diterbitkan. Malang: PPS Universitas Negeri Malang.

Pasaribu, J.F.T. 2005. "Pengaruh Penggunaan Media yang Berbeda dan Gaya Belajar Warga Belajar terhadap Keterampilan Menulis Deskriptif Bahasa Indonesia Kelas I Kejar Paket B Binaan SKB Ende di Susteran CIJ NDONA Ende Nusa Tenggara Timur". Tesis. Tidak Diterbitkan. Malang: PPS Universitas Negeri Malang.

Rose, C dan Nicholl, M. 2002. Accelerated Learning for the 21 st Century. Penerjemah: Dedy Ahimsa. Editor: Purwanto. Bandung: Nuansa.

Serin, O. dan Cyprus, N.N. 2011. "The effects of the Computer-Based Instruction on the Achievement and Problem Solving Skills of the Science and Technology Students". The Turkish Online Journal of Educational Technology. Volume 10 Issue 1. 183-201.

Setyosari, P. 2006. Teori dan Aplikasi: Sistem Online dalam Pembelajaran. Malang: FIP Universitas Negeri Malang.

Setyosari, P. 2009. "Pembelajaran Kolaborasi: Landasan untuk Mengembangkan Keterampilan Sosial, Rasa Saling Menghargai dan Tanggung Jawab". Pidato Pengukuhan Guru Besar. Malang: Universitas Negeri Malang.
Slavin, R.E. 1997. Cooperative Learning: Theory, Research and Practice. Massachusetts: Allyn and Bacon.

Slavin, R.E. 2000. Educational Psychology: Theory and Practice. Needhams Heights, MA: Allyn and Bacon.

Sulistiyawati, R.S. 2011. "Pembelajaran Biologi dengan Menggunakan Media Animasi dan Video Interaktif Ditinjau dari Kreativitas dan Gaya Belajar Siswa". Tesis. Tidak Diterbitkan. Program Pascasarjana Universitas Sebelas Maret.

Surachmad, W. 1990. Pengantar Penelitian Ilmiah: Dasar, Metode, dan Taknik, Edisi VII. Disempurnakan. Bandung: Tarsito.

Triwik Srimulati, Kuswati dan Aprilinawati. 2014. "Perbedaan Pengaruh Metode Pembelajaran Simulasi dengan Latihan (Drill) terhadap Penerapan Pengisian Partograf pada Mahasiswa DIII Kebidanan", $\mathrm{Ca}$ krawala Pendidikan, Februari 2014 th. XXXIII No. 1 LPPMP UNY

Tuckman, B.W. 1999. Conducting Educational Research. New York: Wadsworth Publishing;

Zainudin. 2002. Studi tentang Penerapan Belajar Kooperatif Model STAD dengan Konsentrasi Gaya Kognitif FI dan FD. Journal Teknologi Pembelajaran: Teori dan Penelitian. Tahun 10 Nomor 1. 4556. 